\title{
THE INFLUENCE OF MUSHROOM CORIOLUS VERSICOLOR AND HAZELNUTS ENRICHMENT ON ANTIOXIDANT ACTIVITIES AND BIOACTIVE CONTENT OF DARK CHOCOLATE
}

\author{
Maja S. Kozarski*, Anita S. Klaus, Jovana Đ. Vunduk, Miomir P. Nikšić \\ University of Belgrade, Faculty of Agriculture, Institute of Food Technology and Biochemistry, 11080 \\ Belgrade, Nemanjina 6, Serbia
}

${ }^{*}$ Corresponding author:

Phone: +381 11 441-3142

Fax: +381112199711

E-mail address: maja@agrif.bg.ac.rs

\begin{abstract}
Oxidative stress is among the main culprits for the progression of chronic diseases such as cardiovascular diseases, diabetes, and neurodegenerative disorders. It is well known that dark chocolate possesses polyphenols as major constituents which dietary consumption has been associated to health beneficial effects. Consequently, this study aimed to analyze dark chocolate (DC) and dark chocolate enriched with medicinal mushroom Coriolus versicolor (DCC) and hazelnuts (DCH) regarding antioxidant potential and total polyphenol (TPC), flavonoid (TFC), flavan-3-ol (FLA) and proanthocyanidin (PCA) content. DPPH', CUPRAC and $\mathrm{ABTS}^{\circ+}$ assays were applied for measuring antioxidant capacity. The average of all antioxidant tests for each product was used for calculating the antioxidant potency composite index $(\mathrm{ACl})$. The mean values of all antioxidant assays indicated that all chocolate products contained potent antioxidants. The addition of hazelnuts to dark chocolate significantly affected its total flavonoid content. Regression analysis among results obtained with antioxidant assays revealed that dark chocolate and dark chocolate products may act in mixed mode, by direct reduction via electron transfer or by radical quenching via $\mathrm{H}$ atom transfer. Flavan-3ols had the most significant impact on the ability of the analyzed samples to reduce metals, while proanthocyanidins primarily acted as radical scavengers. The obtained results provided additional information regarding the value-added dark chocolates enriched with bioactive compounds of medicinal mushroom and plant origin.
\end{abstract}

Key words: antioxidant potency composite index, dark chocolate, enriched dark chocolate products

\section{INTRODUCTION}

Chocolate and chocolate products have been consumed throughout human history, but the healthy/unhealthy effects of chocolate have not always been equally recognized. Recently, the determination of secondary metabolites in cocoa and chocolate has changed the long lasting fallacies about the adverse effects of chocolate which has been presented over the last century. Nowadays, chocolate is not only an energy source of sugar and fat mixture, but is also a rich source of polyphenols and methylxanthines which show an important role in protecting human health (Todorovic et al., 2015).

The main polyphenols in chocolate and its products are flavan-3-ols and proanthocyanidins (Laličić-Petronijević et al., 2016). The most biological active are monomeric flavan-3-ols, catechin and epicatechin, and their oligomeric derivativesprocyanidins, members of the proanthocyanidin class of flavonoids (Katz et al., 2011). Flavan-3-ols and procyanidins may contribute to cardioprotective effects via 
antioxidant and antiplatelet activity. They have immunoregulatory properties and beneficial effects on the endothelium (Katz et al., 2011). The epicatechin content of chocolate is primarily responsible for its favorable impact on vascular endothelium, which is the result of both acute and chronic upregulation of nitric oxide production (Galleano et al., 2009). Dark chocolate flavonoids can protect nerves from injury and inflammation and have beneficial effects on satiety, cognitive function, and mood (Katz et al., 2011). In addition to polyphenols, dark chocolate contains methylxanthine compounds, predominantly theobromine and caffeine in small amounts (Todorovic et al., 2015). Theobromine has antioxidant activity similar to caffeine and relatively little stimulating effect on the central nervous system (Todorovic et al., 2015).

Not all chocolates are equally rich in polyphenols and methylxanthines. Nowadays, there are numberless sorts and types of chocolate, starting from different cocoa solids content, the presence of milk or a great variety of additions, fillings and aromatizing agents (Komes et al., 2013). However, consumers are becoming more opting in the food market and they would like to have not just a delicious sweet but also product that can provide sufficient vitality and protection. Therefore, chocolate industry focuses to broaden their product ranges such as having high-cocoa polyphenols rich chocolate, probiotic chocolate, and prebiotic chocolate rather than ordinary chocolate (Gültekin-Özgüven et al., 2016).

Consequently, this study aimed to enrich dark chocolate with medicinal mushroom Coriolus versicolor and hazelnuts, and to compare antioxidant potential of the products. Over the past decade knowledge concerning the health benefits and functioning mechanisms of mushroom supplementation gained much interest in the food nutrition area (Ma et al., 2018). Mushrooms have been consumed for many centuries due to the alluring sensory characteristics, optimal nutritional compositions and for the treatment and prevention of several diseases such as arthritis, rheumatism, bronchitis, gastritis, cancer, as well as in health and longevity maintenance (Soccol et al., 2014). Chocolates with whole nuts or coarse nuts are popular chocolate products and accordingly we used hazelnuts enriched chocolate as the referent standard. Total content of polyphenols (TPC), flavonoids (TFC), flavan-3ols (FLA) and proantho-cyanidins (PCA) was evaluated. Antioxi-dant potency composite index $(\mathrm{ACl})$ was finally used for the evaluation of antioxidant potential.

\section{MATERIALS AND METHODS}

Three samples of each analyzed product: dark chocolate (DC), dark chocolate with C. versicolor (DCC) and dark chocolate with hazelnuts $(\mathrm{DCH})$ were analyzed in order to determine complete antioxidant activity. TPC, TFC, FLA and PCA content of chocolate products were analyzed using spectrophotometric methods.

\section{Sample preparation}

Commercial DC (Selection Noir, Belgium) was used to manufacture chocolate products with $C$. versicolor dried fruiting bodies powder and hazelnuts purchased at a local market specialized for organic food. DC was made from $58 \mathrm{~g} / 100 \mathrm{~g}$ of cocoa mass, $38 \mathrm{~g} / 100 \mathrm{~g}$ of sugar and $4 \mathrm{~g} / 100 \mathrm{~g}$ of cocoa butter. Its nutritional composition and the energetic value were presented in Table 1.

The content of added mushroom and plant material was $5 \%$ in each chocolate product (Komes et al., 2013). Fresh wildgrowing fruiting bodies of autochthonous mushroom species $C$. versicolor were collected from Fruška gora, a large forest area and National park in Vojvodina, Northern Serbia. Carpophores were identified according to the methods of classical herbarium taxonomy to confirm the correct species (Phillips, 1979).

The representative voucher specimens were deposited in the herbarium of the Department for Industrial Microbiology at the Faculty of Agriculture-University of Belgrade (No. CVR-1) together with their mycelial cultures. For further analysis, mushroom samples were soaked in ethanol to remove impurities, lyophilized (Telstar LyoAlfa 15-85, Terrassa, Spain) and powdered. 
Table 1.

Nutritional composition and energetic value of the commercial dark chocolate (DC)

\begin{tabular}{ll}
\hline Nutritional composition & Content $\mathbf{( g / 1 0 0 ~ g ) ~}$ \\
\hline Moisture & $0.87 \pm 0.01$ \\
Total fat & $34.4 \pm 1.2$ \\
Crude protein & $6.7 \pm 0.5$ \\
Carbohydrates & $43.1 \pm 2.0$ \\
-starch & $4.6 \pm 0.3$ \\
-sugars & $38.5 \pm 1.8$ \\
Fibers & $9.8 \pm 0.5$ \\
\hline
\end{tabular}

Energy

$535 \mathrm{kcal} / 100 \mathrm{~g}$

$2215 \mathrm{~kJ} / 100 \mathrm{~g}$

All parameters except moisture were presented on dry weight

Nutritional composition was analyzed according to the Official Methods of Analysis- AOAC procedures (1995)

Total energy was calculated according to Barros et al. (2007)

Raw hazelnuts were manually cracked, then ground in a coffee mill and lyophilized.

\section{Extracts preparation}

The chocolate extracts were prepared as described by Todorovic et al. (2015). Chocolate samples were frozen and manually grated. Exactly $5.0 \mathrm{~g}$ of each cocoa product was extracted three times with $20 \mathrm{~mL}$ of $\mathrm{n}$-hexane in order to eliminate lipids from the samples. Then defatted samples were air-dried during $24 \mathrm{~h}$ to evaporate residues of organic solvent. According to Komes et al. (2013), aqueous acetone was the most efficient to extract the polyphenolic compounds from chocolate products.

Accordingly, the components of interest were extracted from defatted products two times with $35 \mathrm{~mL}$ of solvent extraction mixture (acetone + Milli-Q water (MQ) + acetic acid $(70+29.8+0.2 \mathrm{v} / \mathrm{v} / \mathrm{v})$ for 30 min in an ultrasonic bath (Labsonic LBS210, FALC, Treviglio, Italy). The mixture was centrifuged (Sigma 2-16P, Sigma Laborzentrifugen $\mathrm{GmbH}$, Osterode am Harz, Germany) for 10 min at $3000 \mathrm{rpm}$ after each extraction and the supernatant was decanted.

After filtration to remove the residual particles, the supernatants were combined in a flask and filled up to obtain $100 \mathrm{~mL}$ of the extract. C. versicolor and hazelnuts were extracted according to the same procedure, in order to enable the comparison of the polyphenolic content and antioxidant capacity of chocolate products with mushroom and hazelnuts extracts.
Determination of total polyphenols (TPC), flavonoids (TFC), flavan-3-ols (FLA) and proanthocyanidins (PAC) content

The Folin-Ciocalteu reaction method adapted for a 96-well microplate reader (Hanna Instruments EC 215 Conductivity Meter, Chelmsford, UK) was used to determine the TPC according to Djekic et al. (2016). Gallic acid was used as the standard $(0.015-0.25 \mathrm{mg} / \mathrm{mL})$ and results were expressed as $\mathrm{mg}$ gallic acid equivalents (mg GAE/g of sample, defatted dark chocolate product or dry weight of the $C$. versicolor and hazelnuts extract).

Quantification of TFC was done based on a colorimetric microplate assay (Gajula et al., 2009). Catechin standard solutions $(0.0625-2 \mathrm{mg} / \mathrm{mL})$ were used for the construction of a standard curve. The results are expressed as $\mathrm{mg}$ catechin equivalents (mg CE/g of sample, defatted dark chocolate product or dry weight of the $C$. versicolor and hazelnuts extract).

$\mathrm{PCA}$ were analyzed using a butanol $/ \mathrm{HCl}$ assay described by Todorovic et al. (2015). The quantity of PCA was determined from a standard curve of cyanidin chloride treated with the $\mathrm{BuOH}-\mathrm{HCl}-\mathrm{Fe}$ III mixture and expressed as $\mathrm{mg}$ cyanidin chloride equivalents ( $\mathrm{mg} \mathrm{CyE} / \mathrm{g}$ of sample, de-fatted dark chocolate product or dry weight of the $C$. versicolor and hazelnuts extract). The range of standard solutions $(0.05-0.3 \mathrm{mg} / \mathrm{mL})$ was used for obtaining the calibration curve.

The content of FLA was estimated using the 4-dimethylaminocinnamaldeh (DMAC) 
reagent according to Mraihi et al. (2015). The mentioned method was chosen because of its selectivity, sensitivity, and rapidity to flavan-3-ols quantification compared to other spectrophotometric protocols (Payne et al., 2010). The DMAC react specifically to monomeric flavanols such as catechin and epicatechin of cocoa and chocolate. Little or no reaction occurs with cyanidins and phenolic acids, flavornes, flavanones, flavonols, anthocyanidins, isoflavones, and stilbenes (Payne et al., 2010). The DMAC reagent was prepared immediately before uses, by dissolving $20 \mathrm{mg}$ of DMAC in a cold mixture $(1 / 1 \mathrm{v} / \mathrm{v})$ of methanol and $1.5 \mathrm{M} \mathrm{H}_{2} \mathrm{SO}_{4}$. Extracts $(50 \mu \mathrm{l})$ were added into the wells with 150 $\mu \mathrm{L}$ of DMAC and allowed to react at dark for $10 \mathrm{~min}$, at room temperature. The absorbance at $640 \mathrm{~nm}$ was measured using an absorbance microplate reader (ELx808, BioTek Instruments, Inc., USA). Catechin standard solutions $(0.0125-0.2$ $\mathrm{mg} / \mathrm{mL}$ ) were used for the construction of a standard curve. The results are ex-pressed as mg catechin equivalents (mg CE/g of sample, defatted dark chocolate product or dry weight of the C. versicolor and hazelnuts extract).

\section{Antioxidant activity determination}

Three methods were used to evaluate radical-blocking capacities: 1,1-diphenyl-2picrylhydrazyl free radical (DPPH') scavenging ability, cupric reducing antioxidant capacity (CUPRAC) assay, and 2,2'-azinobis(3-ethylbenzothiazoline-6-sulfonic acid) radical cation $\left(\mathrm{ABTS}^{++}\right)$scavenging ability.

DPPH ${ }^{\circ}$ scavenging ability was evaluated by colorimetric assay (Vunduk et al., 2016) with slight modifications. Briefly, $100 \mu \mathrm{L}$ of aliquoted samples were added to $50 \mu \mathrm{L}$ of freshly prepared dimethyl sulfoxide (DMSO) solution of $0.2 \mathrm{mM}$ DPPH in a 96 well plate (Sarstedt, Nümbrecht, Germany). The absorbance was measured at $490 \mathrm{~nm}$ using a 96-well micro-plate reader (ELx808, BioTek Instruments, Inc., USA). The calibration curve (0.015-1 $\mathrm{mmol}$ Trolox $/ \mathrm{mL}$ ) was used for the quantification of DPPH scavenging ability. The CUPRAC method was done according to Ozturk et al. (2011) with slight modifica- tions. To each well, in a 96 well plate, 50 $\mu \mathrm{L} 10 \mathrm{mM} \mathrm{Cu}$ (II), $50 \mu \mathrm{L} 7.5 \mathrm{mM}$ neocuproine, and $60 \mu \mathrm{L} \mathrm{NH} \mathrm{NA}_{4} \mathrm{Ac}$ buffer $(1 \mathrm{M}$, $\mathrm{pH}$ 7.0) solutions were added. $30 \mu \mathrm{L}$ of aliquoted samples were added to the initial mixture to make the final volume of 190 $\mu \mathrm{L}$. After $1 \mathrm{~h}$, the absorbance was re-corded at $450 \mathrm{~nm}$ against a reagent blank using a 96-well microplate reader. The reagent blank was prepared using the conditions selected in this study, replacing $50 \mu \mathrm{L}$ of $10 \mathrm{mM} \mathrm{Cu}$ (II) with the same volume of $M Q$ water. The CUPRAC was calculated from the calibration curve (0.1$0.8 \mathrm{mmol}$ Trolox $/ \mathrm{mL}$ ). ABTS ${ }^{*+}$ scavenging ability method was slightly modified and adapted for microplate reader by Petrović et al., (2016). Each extract $(50 \mu \mathrm{L})$ was mixed with $200 \mu \mathrm{L}$ of previously activated $\mathrm{ABTS}^{\circ+}$ water solution. The mixture was kept 6 min in the dark and its absorbance was read at $630 \mathrm{~nm}$. The control was prepared by mixing $10 \mu \mathrm{L}$ of $\mathrm{MQ}$ water with $200 \mu \mathrm{L}$ of $\mathrm{ABTS}^{\circ+}$ solution. The calibration curve $(0.2 \mathrm{mmol}-1.5 \mathrm{mmol}$ Trolox $/ \mathrm{mL}$ ) was used for the quantification of $\mathrm{ABTS}^{*+}$ scavenging ability.

The results of all assays were expressed as $\mu \mathrm{mol}$ Trolox equivalents ( $\mu \mathrm{mol} \mathrm{TE} / \mathrm{g}$ of sample, defatted dark chocolate product or dry weight of the C. versicolor and hazelnuts extract.

\section{Antioxidant potency composite index (ACl)}

An overall antioxidant potency composite index was determined by assigning all assays (DPPH', CUPRAC, ABTS ${ }^{\circ+}$ ) an equal weight, assigning an index value of 100 to the best score for each test, and then calculating an index score for all other samples within the test as follows: antioxidant index score $=$ sample score/ best score x100 (Seeram et al., 2008). The average of all three tests for each chocolate product was then taken for the value of antioxidant potency composite index.

\section{Statistical analyses}

All experiments were carried out in triplicate and expressed as the mean \pm standard deviation (SD). Statistical analyses were performed with the Statistica 12.0 software package (Statistica, Tulsa, OK, USA), using a one-way analysis of va- 
riance (ANOVA) for all data collected. Differences between the means for each treatment were determined using Duncan's multiple range tests $(P<0.05)$.

\section{RESULTS AND DISCUSSION}

\section{Total TPC, TFC and PAC content}

There is no uniform method for the extraction of all phenolic compounds with a single solvent system from chocolates and their products (Komes et al., 2013).

Polarities of different phenolic compounds may vary significantly due to their conjugation status and their association with the sample matrix. According to the results of Komes et al. (2013), aqueous acetone was the most efficient to extract polyphenolic compounds from chocolates and dried fruit. Therefore, acetone was selected for the extraction and quantification of polyphenols in this study. TPC, TFC, PCA and FLA contents of dark chocolate, dark chocolate products, $C$. versicolor and hazelnuts extracts were shown in Table 2.

Phenols were found in considerable quantities in all extracts. Dark chocolate samples with or without $C$. versicolor and hazelnuts were similar regarding TPC (Table $2)$. There was no statistical difference observed at $P<0.05$. Flavonoid contents were ranked in the order of $\mathrm{DCH}>\mathrm{DC} \approx \mathrm{DCC}$. TFC in $\mathrm{DCH}$ was statistically different and approximately $11 \%$ higher than in pure DC.

Using the same method for the determination of total phenols and the same extraction solvent, Todorovic et al. (2015)

Table 2.

Polyphenol, flavonoid, proanthocyanidin and flavan-3-ol contents in acetone extracts of dark chocolate, dark chocolate products, C. versicolor and hazelnuts

\begin{tabular}{|c|c|c|c|c|}
\hline Sample & $\begin{array}{c}\operatorname{TPC}^{\dagger} \\
\text { (mg GAE/ g) }\end{array}$ & $\begin{array}{c}\text { TFC }^{\ddagger} \\
\text { (mg CE/g) }\end{array}$ & $\begin{array}{c}\text { PAC }^{! !} \\
\text {(mg CyE/g) }\end{array}$ & $\begin{array}{c}\text { FLA }^{\ddagger} \\
(\mathrm{mg} \mathrm{CE} / \mathrm{g})\end{array}$ \\
\hline DC & $12.3 \pm 0.7^{a}$ & $6.1 \pm 0.3^{6}$ & $2.0 \pm 0.3^{a}$ & $0.70 \pm 0.04^{a}$ \\
\hline DCC & $11.5 \pm 0.4^{a}$ & $5.8 \pm 0.6^{b}$ & $1.5 \pm 0.3^{a}$ & $0.66 \pm 0.08^{a}$ \\
\hline $\mathrm{DCH}$ & $12.6 \pm 0.8^{a}$ & $6.8 \pm 0.3^{a}$ & $1.8 \pm 0.2^{a}$ & $0.76 \pm 0.04^{a}$ \\
\hline $\mathrm{CV}$ & $3.9 \pm 0.3^{c}$ & $0.3 \pm 0.0^{d}$ & $0.09 \pm 0.003^{c}$ & $0.02 \pm 0.002^{c}$ \\
\hline $\mathrm{HA}$ & $7.0 \pm 0.4^{b}$ & $3.2 \pm 0.5^{c}$ & $0.5 \pm 0.0^{\mathrm{b}}$ & $0.47 \pm 0.03^{b}$ \\
\hline
\end{tabular}

${ }^{\dagger}$ gallic acid equivalents (GAE); ${ }^{\ddagger}$ catechin equivalents(CE); "cyanidin chloride equivalents (CyE); all values are expressed per defatted dark chocolate product or dry weight of $C$. versicolor and hazelnuts extract; results are given as mean \pm standard deviation $(n=3)$; within the same column, means followed by different letters are significantly different at $P<0.05$; $D C$ - dark chocolate; $D C C$ - dark chocolate with $C$. versicolor; $D C H$ - dark chocolate with hazelnuts; $\mathrm{CV}-\mathrm{C}$. versicolor extract; $\mathrm{HA}$ - hazelnuts extract

Table 3.

Antioxidant capacity of dark chocolate, dark chocolate products, $C$. versicolor and hazelnuts extracts

\begin{tabular}{cccc}
\hline Sample & $\begin{array}{c}\text { DPPH scavenging } \\
\text { ability } \\
(\mu \mathrm{mol} \mathrm{TE} / \mathrm{g})\end{array}$ & $\begin{array}{c}\text { CUPRAC } \\
(\boldsymbol{\mu m o l ~ T E} / \mathbf{g})\end{array}$ & $\begin{array}{c}\text { ABTS }^{+\bullet} \text { scavenging }^{\text {ability }} \\
(\boldsymbol{\mu m o l ~ T E / g )})\end{array}$ \\
\hline DC & $79.7 \pm 2.1^{\mathrm{a}}$ & $392.5 \pm 6.7^{\mathrm{b}}$ & $256.4 \pm 7.1^{\mathrm{a}}$ \\
DCC & $79.0 \pm 1.6^{\mathrm{a}}$ & $402.7 \pm 10.5^{\mathrm{b}}$ & $249.0 \pm 5.6^{\mathrm{a}}$ \\
DCH & $81.7 \pm 2.4^{\mathrm{a}}$ & $407.5 \pm 8.8^{\mathrm{b}}$ & $255.7 \pm 6.5^{\mathrm{a}}$ \\
HA & $52.2 \pm 2.2^{\mathrm{c}}$ & $69.5 \pm 2.0^{\mathrm{c}}$ & $143.1 \pm 5.5^{\mathrm{c}}$ \\
\hline
\end{tabular}

Results are given as mean \pm standard deviation $(n=3)$; within the same column, means followed by different letters are significantly different at $P<0.05$; $D C$ - dark chocolate; $D C C$ - dark chocolate with $C$. versicolor; $D C H$ dark chocolate with hazelnuts; CV - C. versicolor extract; HA - hazelnuts extract; TE - Trolox equivalents

Table 4.

Antioxidant potency composite index of dark chocolate and dark chocolate products

\begin{tabular}{ccccc} 
Sample & $\begin{array}{c}\text { DPPH } \\
\text { index }\end{array}$ & $\begin{array}{c}\text { CUPRAC } \\
\text { index }\end{array}$ & $\begin{array}{c}\text { ABTS } \\
\text { index }\end{array}$ & $\begin{array}{c}\text { ACI } \\
(\%)\end{array}$ \\
\hline DC & 97.6 & 96.3 & 100 & 97.9 \\
DCC & 96.7 & 98.8 & 97.1 & 97.5 \\
DCH & 100 & 100 & 99.7 & 99.9 \\
\hline
\end{tabular}

DC - dark chocolate; DCC - dark chocolate with C. versicolor; $D C H$ - dark chocolate with hazelnuts; $\mathrm{ACl}$ antioxidant potency composite index 
found an average of $11.99 \mathrm{mg}$ GAE/g of dark chocolate, which was comparable to our study. Flavonoid content found in dark chocolate samples by the same group of authors was in average $20.1 \mu \mathrm{mol} C E / \mathrm{g}$. In order to analyze dark chocolate products, polyphenol contents of CV and HA were determined. Comparing to the dark chocolate and dark chocolate products, polyphenols and flavonoids were found in significantly lower content in C. versicolor and hazelnuts acetone extracts (Table 2). TPC in HA was almost $45 \%$ higher than in $\mathrm{CV}$. TFC of CV and HA were being about $8 \%$ and $46 \%$ of the total phenolics, respectively. As proanthocyanidins are the main flavonoids of cocoa products next to flavan-3-ols, their content was determined. PAC in dark chocolate products varied between $1.5 \mathrm{mg} \mathrm{CyE} / \mathrm{g}$ in DCC and 2.0 $\mathrm{mg} \mathrm{CyE/g} \mathrm{in} \mathrm{DC} \mathrm{(Table} \mathrm{2).} \mathrm{Significant}$ differences were not found between analyzed products $(P<0.05)$, i.e. PAC was not influenced by the presence of $C$. versicolor and hazelnuts extracts (Table 2). Like-wise, significant differences in flavan-3-ol contents were not found between analyzed chocolate products (Table 2). Contrary, FLA were observed an almost twenty four-fold higher content in HA compared to $\mathrm{CV}$. High flavanols content in hazelnuts extract in this study was in agreement with the research of Slatnar et al. (2014). They confirmed that the main polyphenolic subclass in hazelnut kernels comprised of mono- and oligomeric flavan 3-ols.

Structurally, flavonoids are classified into 12 major subclasses based on chemical structures, six of which, namely anthocyanidins, flavan-3-ols, flavonols, flavornes, flavanones, and isoflavones are of dietary significance (Manach et al., 2004; Kumar and Pandey, 2013). This structural diversity results in large variability of the physico-chemical properties influencing the extraction of polyphenols (Koffi, 2010).

Dark chocolate, hazelnuts and C. versicolor fruiting bodies are compositionally different substrates and maximum extraction efficiency of polyphenolic compounds could not be achieved with the same solvent, since they contain, to a certain ex- tent, different types of polyphenolic compounds (Hammerstone et al., 1999; Natsume et al., 2000; Jakopic et al., 2011; Slatnar eta al., 2014; Janjušević et al., 2017; Cerulli et al., 2018). Additionally dark chocolate with hazelnuts and $C$. versicolor combined together can produce a complex matrix, and more extraction solvents of different polarity would be appropriate to compare the contents of polyphenols in the final products (MojzerBrglez et al., 2016). Consequently, further investigations are necessary to verify maximum quantities and qualitative profile of polyphenols that can be obtained by consuming these products.

\section{Antioxidant capacity of dark chocolate products}

Three different antioxidant assays $\left(\mathrm{ABTS}^{\circ}\right.$, $\mathrm{DPPH}^{\circ}$, and CUPRAC) were applied for the evaluation of the antioxidant capacity of chocolate extracts and the obtained results were shown in Table 3.

The mean values of all antioxidant assays indicated that all chocolate extracts contained potent antioxidants. Significant differences were not observed between dark chocolate extracts in DPPH', CUPRAC and $\mathrm{ABTS}^{\circ+}$ assay. Increased TFC content in $\mathrm{DCH}$ was not followed by the increasing of the antioxidant potential. CA and HA had lower DPPH' and $\mathrm{ABTS}^{*+}$ scavenging abilities in the comparison of the dark chocolate products and it was in agreement with lower contents of polyphenolic, flavornoid, proanthocyanidin and flavan-3-ols observed (Table 2).

However, HA showed the highest potential in CUPRAC assay and reduction of $\mathrm{Cu}^{2+}$ to $\mathrm{Cu}^{+}$among all analyzed extracts (Table 3) which may indicate that the qualitative composition of the extracts is of more importance than the quantity. Mira et al. (2002) showed that the $\mathrm{Cu}$ reducing activity seems to depend largely on the number of hydroxyl groups present in the polyphenols molecules, having their basic structures a small influence.

Significantly lower reduction ability of $\mathrm{DCH}$ compared to HA (Table 3) could be explained by the interaction of matrix components of the new chocolate products. 


\section{Correlation between the antioxidant potential and components of chocolate extracts}

In order to better understand mechanism of antioxidant action, the correlation coefficients ( $r$ ) among results obtained with antioxidant assays, and antioxidant assays with the content of bioactive components of chocolate extracts were determined.

Correlations among results obtained with antioxidant assays were positively strong for DPPH ${ }^{\circ}$ and CUPRAC ( $\left.r=0.81\right)$, as well as $\mathrm{DPPH}^{\circ}$ and $\mathrm{ABTS}^{\circ+}(\mathrm{r}=0.89)$. Moderate, positive correlation was observed between ABTS $^{\circ+}$ and CUPRAC ( $\left.r=0.52\right)$.

It has been established that antioxidants can demonstrate their protective properties at different stages of the oxidation process and by different mechanisms (Gordon, 1990). There are two main types of antioxidants, namely, primary (chain breaking, free radical scavengers) and secondary or preventive (Gordon, 1990). Secondary antioxidants are the consequence of deactivation of metals, inhibition or breakdown of lipid hydroperoxides, regeneration of primary antioxidants, singlet oxygen $\left({ }^{1} \mathrm{O} 2\right)$ quenching, etc.

The assays for measuring antioxidant capacity used in this study are based on different mechanisms. CUPRAC mea-sures the ability of a sample to reduce metals while ABTS and DPPH measure a sample's free radical scavenging capacity (Gordon, 1990; Prior et al., 2005). Besides in FRAP, there is a SET (Single Electron Transfer) reaction mechanism, while DPPH and ABTS combine both, a HAT (Hydrogen Atom Transfer) reaction and SET reaction mechanism (Prior et al., 2005).

From the results obtained from correlation analysis among the antioxidant assays it could be concluded that dark chocolate and dark chocolate products may act in mixed mode, by direct reduction via electron transfers or by radical quenching via $\mathrm{H}$ atom transfer.

As a confirmation, the correlations between antioxidant assays and the content of bioactive components inferred: 1. TPC very strong and positive correlation with DPPH $^{\circ}$ and ABTS $^{\circ+}(r=0.94$ and $r=0.96)$, and moderate with CUPRAC ( $r=0.55) ; 2$. TFC - very strong positive correlation with $\mathrm{DPPH}^{\circ}(\mathrm{r}=0.90)$, and strong with $\mathrm{ABTS}^{\circ+}$ and CUPRAC ( $r=0.77$ and $r=0.73) ; 3$. PCA - very strong positive correlation with ABTS $^{+} \quad(r=0.94)$, strong with $\mathrm{DPPH}^{\circ}$ $(r=0.70)$ and weak with CUPRAC ( $r=0.21)$; 4. FLA - very strong and positive correlation with $\mathrm{DPPH}^{\circ}(\mathrm{r}=0.92)$, and strong with ABTS $^{*+}(r=0.84)$ and CUPRAC $(r=0.84)$.

Results of regression analysis indicated that flavan-3-ols exerted the most significant impact on the ability of analyzed samples to reduce metals, while proanthocyanidins primarily acted as radical scavengers.

\section{Antioxidant potency composite index (ACl)}

We used three different methods to determine antioxidant capacity. Each of these methods for antioxidant activity has certain advantages and limitations and differs in terms of the assay principles (Prior et al., 2005). Consequently, in order to give equal weight to these entire methods $\mathrm{ACl}$ was calculated. Although in vitro antioxidant capacity cannot be directly translated to biological systems, $\mathrm{ACl}$ presents a useful tool for ranking different commercial products (Seeram et al., 2008). The $\mathrm{ACl}$ values are shown in Table 3 . $\mathrm{DCH}$ had the highest average $\mathrm{ACl}$ value of $99.9 \%$ among tested samples (Table 4).

\section{CONCLUSIONS}

The results of the present study confirmed the antioxidant potential of dark chocolate and dark chocolate enriched with $C$. versicolor mushroom and hazelnuts.

However, the addition of $5 \%$ of $C$. versicolor and hazelnuts to dark chocolate had no influence on antioxidant potential and total polyphenols, flavan-3-ols and proanthocyanidins contents of the enriched products. Contrary to this observation, changes in total flavonoid content were observed in the dark chocolate sample enriched with hazelnuts. Regression 
analysis among results obtained with antioxidant assays revealed that dark chocolate and dark chocolate products may act in mixed mode, by direct reduction via electron transfer or by radical quenching via $\mathrm{H}$ atom transfer. Flavan-3-ols had the most significant impact on the ability of analyzed samples to reduce metals, while proanthocyanidins primarily acted as radical scavengers.

The obtained results provided additional information regarding the high valuable dark chocolates enriched with bioactive compounds of medicinal mushroom and plant origin. Further studies are needed to investigate the qualitative and quantitative diversity of polyphenols subclasses which are present in analyzed samples and subclasses impact on antioxidant mechanisms.

\section{ACKNOWLEDGEMENTS}

The study was supported by the Serbian Ministry of Science and Technological Development, Project Numbers III 46001 and III 46010.

\section{REFERENCES}

1. AOAC (1995). Official Methods of Analysis of AOAC International, $16^{\text {th }}$ Ed., AOAC International, Arlington, VA, USA.

2. Barros, L., Baptista, P., Correia, D.M., Casal, S., Oliveira, B., Ferreira, I.C.F.R. (2007). Fatty acid and sugar compositions and nutritional value of five wild edible mushrooms from Northeast Portugal. Food Chemistry, 105, 140145.

3. Bonetti, F., Brombo, G., Zuliani, G. (2017). Nootropics, functional foods, and dietary patterns for prevention of cognitive decline. In $\mathrm{Nu}$ trition and functional foods for healthy aging. Ed. R.R. Watson, Academic Press, Cambridge, Massachusetts, pp. 211-232.

4. Cerulli, A., Napolitano, A., Masullo, M., Pizza, C., Piacente, S. (2018). LCESI/LTQOrbitrap/MS/MS ${ }^{n}$ analysis reveals diarylheptanoids and flavonol O-glycosides in fresh and roasted hazelnut (Corylus avellana cultivar "Tonda di Giffoni"). Natural Product Communications, 13, 1123-1126.

5. Djekic, I., Vunduk, J., Tomašević, I., Kozarski, M., Petrovic, P., Niksic, M., Pudja, P., Klaus, A. (2017). Total quality index of Agaricus bisporus mushrooms packed in modified atmosphere. Journal of the Science of Food and Agriculture, 97, 3013-3021.

6. Gajula, D., Verghese, M., Boateng, J., Walker, L.T., Shackelford, L., Mentreddy, S.R., Cedric, S. (2009). Determination of total phenolics, fla- vonoids and antioxidant and chemopreventive potential of basil (Ocimum basilicum L. and Ocimum tenuiflorum L.). International Journal of Cancer Research, 5, 130-143.

7. Galleano, M., Oteiza, P.I., Fraga, C.G. (2009). Cocoa, chocolate and cardiovascular disease. Journal of Cardiovascular Pharmacology, 54, 483-490.

8. Gordon, M.H. (1990). The mechanism of antioxidant action in vivo. In Food Antioxidants. Ed. B.J.F. Hudson, Elsevier, London, pp. 1-18.

9. Gültekin-Özgüven, M., Karadag, A., Duman, S., Özkal, B., Özçelik, B. (2016). Fortification of dark chocolate with spray dried mulberry (Morus nigra) waste extract encapsulated in chitosan-coated liposomes and bioaccesability studies. Food Chemistry, 201, 205-212.

10. Hammerstone, J.F., Lazarus, S.A., Mitchell, A.E., Rucker, R., Schmitz, H.H. (1999). Identification of procyanidins in cocoa (Theobroma cacao) and chocolate using high-performance liquid chromatography/mass spectrometry. Journal of Agricultural and Food Chemistry, 47, 490-496.

11. Jakopic, J., Mikulic Petkovsek, M., Likozar, A., Solar, A., Stampar, F., Veberic, R. (2011). HPLC-MS identification of phenols in hazelnut (Corylus avellana L.) kernels. Food Chemistry, 124, 1100-1106.

12. Janjusevic, Lj. Karaman, M., Sibul, F., Tommonaro, G., lodice, C., Jakovljevic, D., Pejin, B. (2017). The lignicolous fungus Trametes versicolor (L.) Lloyd (1920): a promising natural source of antiradical and AChE inhibitory agents. Journal of Enzyme Inhibition and Medicinal Chemistry, 32, 355-362.

13. Katz, D.L., Doughty, K., Ali, A. (2011). Cocoa and chocolate in human health and disease. Antioxidants and Redox Signaling, 15, 27792811.

14. Koffi, E., Sea, T., Dodehe Y., Soro, S. (2010). Effect of solvent type on extraction of polyphenols from twenty three Ivorian plants. Journal of Animal and Plant Sciences, 5, 550-558.

15. Komes, D., Belscak-Cvitanovic, A., Skrabal, S., Vojvodic, A., Busic, A. (2013). The influence of dried fruits enrichment on sensory properties of bitter and milk chocolates and bioactive content of their extracts affected by different solvents. LWT - Food Science and Technology, 53, 360369.

16. Kumar, S., Pandey, A.K. (2013). Chemistry and biological activities of flavonoids: an overview. Scientific World Journal, 2013, 162750.

17. Laličić-Petronijević, J., Komes, D., Gorjanović, S., Belščak-Cvitanović, A., Pezo, L., Pastor, F., Ostojić, S., Popov-Raljić, J., Sužnjević, D. (2016). Content of total phenolics, flavan-3-ols and proanthocyanidins, oxidative stability and antioxidant capacity of chocolate during storage. Food Technology and Biotechnology, 54, 13-20.

18. Ma, G., Yang, W., Zhao, L., Pei, F., Fang, D., $\mathrm{Hu}, \mathrm{Q}$. (2018). A critical review on the health promoting effects of mushrooms nutraceuticals. Food Science and Human Wellness, 7, 125133. 
19. Manach, C., Scalbert, A., Morand, C., Remesy, C., Jimenez, L. (2004). Polyphenols: food sources and bioavailability. American Journal of Clinical Nutrition, 79, 727-747.

20. Mira, L., Fernandez, T.M., Santos, M., Rocha, R., Florencio, H.M., Jennings, K.R. (2002). Interactions of flavonoids with iron and copper ions: A mechanism for their antioxidant activity. Free Radical Research, 36, 1199-1208.

21. Mojzer Brglez, E., Hrnčič Knez, M., Škerget, M., Knez, Ž., Bren, U. (2016). Polyphenols: extraction methods, antioxidative action, bioavailability and anticarcinogenic effects. Molecules, 21, 901.

22. Mraihi, F., Sidaoui, F., Hidalgo, M., de Pascual -Teresa, S., Trabelsi-Ayadi, M., Cherif, J.K. (2015). The 4-dimethylaminocinnamaldehyde flavanols quantification assays in Tunisian Crataegus monogyna and their HPLC-MS profiling. Tunisian Journal of Medicinal Plants and Natural Products, 13, 1-7.

23. Natsume, M., Osakabe, N., Yamagishi, M., Takizawa, T., Nakamura, T., Miyatake, H., Hatano, T., Yoshida, Y. (2000). Analyses of polyphenols in cacao liquor, cocoa, and chocolate by normal-phase and reversed-phase HPLC. Bioscience, Biotechnology, and Biochemistry, 64, 2581-2587.

24. Ozturk, M., Duru, M.E., Kivrak, S., MercanDogan, N., Turkoglu, A., Ozler, M.A. (2011). In vitro antioxidant, anticholinesterase and antimicrobial activity studies on three Agaricus species with fatty acid compositions and iron contents: A comparative study on the three most edible mushrooms. Food and Chemical Toxicology, 49, 1353-1360.

25. Payne, M.J., Hurst, W.J., Stuart, D.A. (2010). Determination of total procyanidins in selected chocolate and confectionery products using
DMAC. Journal of AOAC International, 93, 8995.

26. Petrović, P., Vunduk, J., Klaus, A., Kozarski, M., Nikšić, M., Žižak, Ž., Vuković, N., Šekularac, G., Drmanić, S., Bugarski, B. (2016). Biological potential of puffballs: a comparative analysis. Journal of Functional Foods, 21, 3649.

27. Phillips, R. (1979). Mushrooms and Other Fungi of Great Britain and Europe, Macmillan, New York.

28. Seeram, P.N., Aviram, M., Zhang, J., Henning, M. S., Feng, L., Dreher, M., Heber, D. (2008). Comparison of antioxidant potency of commonly consumed polyphenolrich beverages in the United States. Journal of Agricultural and Food Chemistry, 56, 1415-1422.

29. Soccol, C.R., Fan, L., Habu, S. (2014). Biological properties of mushrooms. In Food composition and analysis: methods and strategies. Eds. A.K. Haghi, E. Carvajal-Millan, Apple Academic Press, New York, pp. 1-36.

30. STATISTICA (Data Analysis 12.0 Software System) (2013). Stat-Soft, Inc., Tulsa, OK, USA (www.statsoft.com).

31. Todorovic, V., Radojcic Redovnikovic, I., Todorovic, Z., Jankovic, G., Dodevska, M., Sobajic, S. (2015). Polyphenols, methylxanthines, and antioxidant capacity of chocolates produced in Serbia. Journal of Food Composition and Analysis, 41, 137-143.

32. Vunduk, J., Klaus, A., Kozarski, M., Djordjevic, R., Miladinovic, Z., Jovanovic, Lj., Niksic, M., van Griensven, L. (2016). Addition of zeolites to improve the functional characteristics of the Hen of the Wood or Maitake medicinal mushroom, Grifola frondosa (Agaricomycetes). International Journal of Medicinal Mushrooms, 18, 781-792. 


\title{
УТИЦАЈ ДОДАТКА ЛЕКОВИТЕ ГЉИВЕ CORIOLUS VERSICOLOR И ЛЕШНИКА НА АНТИОКСИДАТИВНИ ПОТЕНЦИЈАЛ И БИОАКТИВНИ САДРЖАЈ ЦРНЕ ЧОКОЛАДЕ
}

\author{
Маја С. Козарски*, Анита С. Клаус, Јована Ђ. Вундук, Миомир П. Никшић \\ Универзитет у Београду, Пољопривредни факултет, Институт за прехрамбену технологију и \\ биохемију, 11080 Београд, Немањина 6, Србија
}

\begin{abstract}
Сажетак: Оксидативни стрес је одговоран за напредовање хроничних обољења као што су кардиоваскуларне болести, дијабетес и неуродегенеративни поремећаји. Познато је да црна чоколада садржи полифеноле чији унос остварује позитиван утицај на здравље. Сходно томе, циљ овог истраживања био је да се анализира антиоксидативни потенцијал и укупни садржај полифенола (TPC), флавоноида (TFC), флаван-3-ола (FLA) и проантоцијанидина (PCA) црне чоколаде (DC) и црне чоколаде са додатком гљиве Coriolus versicolor (DCC) и лешника

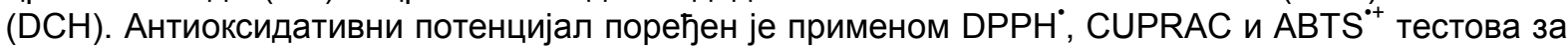
мерење антиоксидативних способности in vitro. Средња вредност свих антиоксидативних тестова за сваки анализирани производ коришћена је за израчунавање антиоксидативног композитног индекса (ACI). Резултати истраживања су показали да DC, DCC и DCH имају изражени антиоксидативни потенцијал. Додавање лешника тамној чоколади значајно је утицало на њен укупни садржај фрлавоноида. Регресиона анализа резултата добијених антиоксидативним тестовима је потврдила да DC, DCC и DCH испољавају антиоксидативни потенцијал различитим реакционим механизмима тј. директном редукцијом преношењем електрона и хватањем слободних радикала преношењем водоникових атома. Потврђено је да фолаван-3-оли имају значајан утицај на способност анализираних узорака да редукују метале, док проантоцијанидини углавном делују као хватачи слободних радикала. Добијени резултати овог истраживања пружају додатне информације о биолошком потенцијалу црне чоколаде са додатком биоактивних компонената биљног порекла и лековитих гљива.
\end{abstract}

Кључне речи: антиоксидативни композитни индекс, ирна чоколада, црна чоколада са додацима лековите гљиве и лешника

Received: 5 November 2019

Received in revised form: 18 December 2019

Accepted: 3 February 2020 